\title{
Mechanisms of greater cardiomyocytes functions on conductive nanoengineered composites for cardiovascular applications. [Corrigendum]
}

Stout DA, Yoo J, Noemi Santiago-Miranda AN, Webster TJ International Journal of Nanomedicine 2012,7:5653-5669

An author was incorrectly listed as Noemi Santiago-MirandaA, but should be listed as:Santiago-Miranda AN.

In addition, the correct spelling for Santiago-Miranda AN institution affiliation is Mayagüez instead of Mayagües.

International Journal of Nanomedicine

\section{Publish your work in this journal}

The International Journal of Nanomedicine is an international, peerreviewed journal focusing on the application of nanotechnology in diagnostics, therapeutics, and drug delivery systems throughou the biomedical field. This journal is indexed on PubMed Central, MedLine, CAS, SciSearch ${ }^{\circledR}$, Current Contents ${ }^{\circledR} /$ Clinical Medicine,
Journal Citation Reports/Science Edition, EMBase, Scopus and the Elsevier Bibliographic databases. The manuscript management system is completely online and includes a very quick and fair peer-review system, which is all easy to use. Visit http://www.dovepress.com/ testimonials.php to read real quotes from published authors. submit your manuscript | www.dovepress.com

Dovepress

http://dx.doi.org// 0.2147/IJN.S40500 